https://doi.org/10.15407/socium2020.01.041

UDC 316.25:316.472.3:316.613.4

Yashkina D.D., PhD student, Department of Political Sociology V.N. Karazin Kharkiv National University, Freedom Square, 4, Kharkiv, 21022, Ukraine, email: yashkinadarya96@gmail.com, ORCID iD: https://orcid.org/0000-0003-4454-4555

\title{
HEURISTIC POTENTIAL OF EMOTIONAL LABOR CONCEPTS, TRUST AND PUBLIC SPACE IN THE STUDY OF "SOLO-LIVING"
}

This article attempts to identify the heuristic potential of the concepts of A. Hochschild, D. Gambetta, and $R$. Sennett in the study of the "solo-living" phenomenon. Considering the concepts of emotional work, public and personal spaces, as well as trust, the author considers the possibility of applying the concepts in the study of non-family forms of partnership. In the analysis of concepts it is determined that they could potentially explain the occurrence and development of such forms as "solo-living". Through the prism of the sociology of emotions by A. Hochschild, the author of the article examines the unwillingness or inability to perform emotional work as one of the factors about the increasing number of individuals living alone. At the same time, R. Sennett's concept shows how "solo-living" arises in response to the absorption of personal space by the public, and one of the premises of "solo-living", according to the concept of trust of D. Gambetta, is weak family ties. The author comes to a conclusion that the concepts have heuristic potential for the study of these phenomena but do not claim to be exhaustive. The limitations of the study are indicated: for example, the concept of emotional labor concerns mainly women, while ignoring the study of the difficulties that men may encounter in the context of a given problem, which also seems necessary from the author's point of view; R. Sennett focuses on urban space. In its turn globalization erases the boundaries between cities and countries, thereby making the space global, which acquires special significance in the context of studying, for example, such a form of partnership as distance relations - which can also be considered in the context of the phenomenon of "solo-living" study. The author also discusses the prospects for further research of "solo-living" within the framework of the concepts of A. Hochschild, D. Gambetta and $R$. Sennett and also raises the research question about the possibility of synthesizing the presented concepts as an explanatory model for the development of various forms of partnership.

Keywords: the phenomenon of "solo-living", social change, sociology of emotions, public and private space, trust.

Яикіна Д.Д., аспірантка кафедри політичної соціології Харківського національного університету імені В.Н. Каразіна, пл. Свободи, 4, Харків, 61022, Україна, етаіl: yashkinadarya96@gmail.com,ORCID iD: https://orcid.org/0000-0003-4454-4555

\section{ЕВРИСТИЧНИЙ ПОТЕНЦАЛ КОНЦЕПЦІЙ ЕМОЦІЙНОЇ ПРАЦІ, ДОВІРИ ТА ПУБЛІЧНОГО ПРОСТОРУ В ДОСЛІДЖЕННІ “SOLO-LIVING”}

Здійснено спробу виявити евристичний потенціал конщепцій А. Хохиильд, Д. Гамбетта $i$ P. Сеннетта в дослідженні феномену "solo-living". Аналізуючи концепції емоційної пращі, суспільного й індивідуального просторів, а також довіри, розглянуто можливості застосування иих концепџій у вивченні несімейних форм партнерських взаємин. Під час аналізу циих конщепцій визначено, як вони можуть пояснювати виникнення та розвиток таких форм, як "solo-living”. При иьому зосереджено увагу на аналізі факторів поширення феномену "sоloliving”, зокрема на таких, як небажання або неможливість виконання емоційної роботи (за соиіологією емоцій А. Хохшильд), поглинання особистого простору публічним (за концепцією Р. Сеннетта) та слабкі сімейні зв'язки (згідно з конщепцією довіри Д. Гамбетта). Доведено, щзо названі концепиії мають евристичний потенціал для дослідження зазначеного феномену, не

(C) Yashkina D.D., 2020

ISSN 1681-116X. Ukrainian Society, 2020, № 1 (72): 41-51 
Yashkina D.D.

\begin{abstract}
претендуючи на те, щчоб бути вичерпними. Визначено обмеження використання ичих конщепцій при вивченні “solo-living”. Так, концепція емоційної праці стосується переважно жінок, ігноруючи при цььому ті труднощі, з якими можуть стикатися чоловіки в контексті заданої проблематики, щзо також, на думку автора, вважається за необхідне. У своїй концепиії Р. Сеннет зосереджується на міському просторі, незважаючи на те, щзо прочеси глобалізації стирають кордони між містами та країнами, тим самим роблячи простір глобальним, щуо набуває особливої значущзості в контексті вивчення, наприклад, такої форми партнерства, як відносини на відстані, які теж можна розглядати як одну з форм феномену "solo-living". Визначаючи перспективи подальших досліджень "solo-living” у рамках концепчій А. Хохшильд, Д. Гамбетта і Р. Сеннета, автор ставить дослідницьке питання про можливість синтезування основних ідей представлених концепцій як пояснювальної моделі розвитку різноманітних форм партнерських відносин.
\end{abstract}

Ключові слова: феномен "solo-living”, сочіальні зміни, сочіологія емоцій, публічний $i$ приватний простори, довіра.

Nowadays, we are increasingly dealing with a situation where a person, despite the fact that he/she existed collectively (according to generally accepted ideas), chooses solitude. Partnerships take various forms, are modified and, ultimately, can lead to their complete absence. One of these trends is the fact that modern young people - young adults - are paying less and less attention to creating a family in the common sense that we have established for us. Increasingly, we are talking about the appearance, but more precise, increasing distribution of new forms of partnership ${ }^{1}$ : long-distance relationships, weekend families, separate families, single people and many other forms of human coexistence. Some forms are developing faster and more actively: for example, relations at a distance are becoming an increasingly popular form of partnership, the number of such relations is growing, and researchers distinguish different types among them ${ }^{2}$. Other forms, such as "solo-living" or living alone, have been studied insignificantly. However, at the same time they are of potential interest for economy, politics, and sociology, where they are very blurry. Before studying them, it is necessary to understand the nature of the origin of these forms: why it became necessary to change the established form of the family and what provoked it.

When describing this problem, intuitively an explanation of its individualization processes that are characteristic of modern societies arises, but the mechanism itself remains not so obvious. The study of new forms of partnership began to develop rapidly since the early 2000s, however, the first researches, for example, of the phenomenon of single living can be found back in the mid $80 \mathrm{~s}^{3}$.

Studies primarily consider the emergence of various forms of partnership as a result of individualization, which, in turn, is caused by globalization (that is, this process is analyzed

\footnotetext{
${ }^{1}$ Thus, the OECD report "The Future of Families until 2030" predicts a change in family forms and provides recommendations on adapting social policies to such new conditions [1].

${ }^{2}$ A Lithuanian researcher, Iveta Jurkane-Hobain, studying relationships at a distance, says that now they distinguish different types of such relationships: relations at a distance, living separately-together, commuting pairs, etc. [2].

${ }^{3}$ For example, [3].
} 
at the macro level), but usually focus is on the consequences of the development and popularization of such forms. The study of the prerequisites and reasons for the emergence of new forms of partnership (as well as the "solo-living" phenomenon, which we will focus on in the future) remains in the shadow at the micro level and the conceptual basis of such changes. Studies are conducted pointwise, most often in the framework of gender studies and in the field of economics (household studies) within a particular state, while they are not considered as independent phenomena that have potential global consequences, both for the economy and for the social sphere.

In the framework of sociology of the family, the emergence and transformation of relationships and the reduction of household sizes were studied by Goode [4], Keilman [5], Ayad, Barrer and Otto [6], Bongaarts [7], Fokkema and Liefbroer [8], Stone [9]. This problem acquires particular relevance when considering post-Soviet countries where globalization processes proceed differently from Western countries, which is due to the closed borders of the USSR and socialist tradition. However, existing studies consider the phenomenon of "solo-living", for example, only at the local level. That is why we propose to analyze several concepts that, in our opinion, have heuristic potential for the problem described by us. These concepts embrace changes in the globalization process and reflect three socially global issues: the economic, the problem of trust, and the problem of publicity in the modern world. In our opinion, this may become the foundation for the study of "sololiving".

In this regard, the aim of this article is to identify the potential of heuristic tool concepts of A. Hochschild, D. Gambetta and R. Sennett to identify the preconditions and causes of the emergence and development of new forms of partnership.

These concepts were selected by us for analysis for several reasons. They represent different approaches to the study of social: the theory of games and rational choice in the concept of D. Gambetta, the sociology of emotions of A. Hochschild, urban studies and the study of public and private spaces of R. Sennett. At the same time, these concepts consider mainly the correlation of micro-level consequences of the development of capitalism, changes in labor relations and the transformation of private space. Being different, all these concepts are assumed by us as such, which will allow us to undertake an instrumental analysis of the emotional side of social relations, the study of which is increasingly turning to modern sociology.

In a modern individualized society, such phenomenon as emotional culture arises; issues of correlation of emotional and rational, etc. are actualized [10, pp. 2-8]. One of the founders of this trend is Arly Russell Hochschild, an American sociologist of the Marxist trend, who specializes in the sociology of emotions, and emotional labor is the central concept for her. It is of interest to us, as it transforms emotions into a social construct, considered one of the main components of interpersonal interaction. With the development of the market, a number of professions arise and that require the employee to develop not only mechanical, manual, intellectual, but also emotional labor. So, as an example, the author cites flight attendents, whose task is not only to provide services such as lunch delivery, passenger control and first aid, but also to keep passengers calm in emergency situations. This, according to A. Hochschild, requires control over one's own emotions: under any 
circumstances, calmness and goodwill should be demonstrated, even if in reality the inner sensations are different; this is called emotional labor. Here it is heuristically important for us to note that the author separates the concepts of "emotional work" and "emotional labor", where "emotional work" is the effort to manage emotions that we carry out in the process of all social life, and "emotional labor" is only that part of the emotional work that is carried out in the framework of professional activity and involves payment $[11 ; 12]$. Turning to the phenomenon of the spread of non-family forms of partnerships, we can assume that such work of one or two partners creates a situation where emotional work ceases to seem necessary if it is not labor (unpaid). On the other hand, the development of such forms as single living, for example, allows an individual to choose when to communicate with a partner, and also when he / she or they both are ready for emotional work, which removes the effect of the constant need for emotional work.

Ultimately, emotional labor, according to A. Hochschild and in the spirit of Marxism, leads to "emotional estrangement" - estrangement from one's own feelings. In its critical manifestations, it boils down to the fact that the stewardess's smile does not belong to the stewardess herself, but to the airline that sells that smile [11, pp. 4-23]. Such alienation can affect not only professional activity, when a smile belongs to the company, it belongs to it everywhere, and the process of "switching" from a "working smile" to a "home one", ultimately from emotional work to emotional work, can take a certain or an indefinite amount of time, which requires an individual from a kind of "solitude" from emotional work.

Speaking of emotional labor, A. Hochschild makes emphasis on the gender affiliation, continuing his research, the author refers to the research of working women and their families: coming home from work and performing their paid work, women are faced with the need to carry out unpaid work, family. In this case, as A. Hochschild says, one of the main problems is the redistribution of household responsibilities in family life between partners, and such attempts to distribute responsibilities have emotional consequences [13], which can lead, for example, to divorce if we are talking about official families (registered). And in this case, the next question arises: will an individual, after a similar break in relations, enter into relations involving the same redistribution of responsibilities? Are they ready to start a family again? Such individuals can find a way out precisely in relations at a distance or in "solo-living", when there is no need to divide and distribute something and the individual is left to his / her own duties.

In this context, A. Hochschild says more about women and the implementation of the function of caring for children and the family as such, including both the spouse and parents. Here, the so-called "sandwich syndrome" [14] can often occur, which is expressed in the fact that women are caught between the realization of the function of caring for the younger and older generations, while receiving a double emotional burden. Moreover, women often also work in such conditions. Relationships at a distance and solitary living can be one of the ways, if not avoiding, then distancing oneself from being in such a "sandwich".

Considering the family as a place of expression of care and love, A. Hochschild argues that this care is increasingly often bought in the modern world and sellers are the nurses, who care for children while their parents are at work, the nurses, who care for their parents, while 
Heuristic potential of emotional labor concepts...

their children are busy. There is a situation in which it is easier to buy care than to express it [13]. That is, people who choose single living, can also be seen as the spacers themselves from the emotional work space by shifting it onto the shoulders, for whom this is their labor.

Thus, we fix several elements that are important to us. Feelings are commercialized, therefore, the "missing feeling" can be acquired and the individual can choose what is easier for him / her: to give his / her own care on his / her own or just buy this service, for example. Awareness of this and emotional work leads to a kind of emotional exhaustion, when, using the terminology of I. Goffman, having played the role of a calm and smiling flight attendant, an individual cannot, when he / she comes home, also play the role of caring and happy spouses, parents, children. If we consider emotional energy, and this is how emotions were considered by I. Goffman, for interpersonal interactions [15, p. 20], then the energy is finite, and having exhausted it at work, a person needs to recover it outside of work instead of continuing to spend it. Moving from the personal space to the public space, such resources are consumed faster: after all, the resource itself is accumulated and stored in the entire narrowing personal space.

That is, more and more developing emotional labor causes the need for a greater temporal and spatial resource for the individual. One of the ways an individual organizes such a space for himself / herself is the "solo-living" lifestyle, when the individual consciously protects himself / herself from the outside world by the boundaries of his / her apartment/house, etc.

Considering the emotional component of social interactions, resorting to the dramatic approach of I. Hoffmann, which A. Hochschild relied on, and to the concept of emotional work itself, we see that the connection between personal and public spaces runs through the presented concept, and one of the main problems is just the balance between these two spaces. The relevance of this problem increases with the development of urban life as such: life goes on more intensively, there are more and more social ties, and personal space is less.

So, R. Sennett, an American sociologist-urbanist, considers the city from the point of view of labor and the sociology of culture, including the nature of the relationship between family and work in the city. With the development of urban space, he connects the formation of the nuclear type of the family as one of the most common in cities [16]. The nuclear type of family for the only developing urban space was the most rational: on the one hand, feminist movements were just beginning to develop actively and the traditional distribution of roles was working (a man works, a woman cooks, using stereotyped language), and on the other hand, the maintenance of large families in the city became almost impossible, since it was unprofitable and impractical both in the spatial sense and in the economic one. The desire to rationalize and to save space, on the one hand, and all of a broad representation of the urban lifestyle "solo-living", striving for economic independence, on the other, lead to the spread of single households.

Considering the prerequisites for the modern society formation through the prism of the modern cities formation, studying their history, R. Sennett comes to the central categories in his idea of the formation of the city space - "privacy" and "publicity". R. Sennett, having studied in detail the history of the meaning of these terms, concluded that a modern 
understanding of the public (as open to all and full of friends and strangers) and private (closed and consisting of family and close friends) was formed by the end of the 17th century. Then everything outside the family became public [17]. The life that proceeds behind closed doors of the house remains inaccessible to the public; it is not customary to talk openly about family life.

Considering the public sphere, R. Sennett identifies three approaches to its study: the approach of $\mathrm{H}$. Arendt, according to which the public sphere is the space of expression of individuality; J. Habermas's view of the public sphere as a space for reaching consensus, agreement; and finally, the approach of K. Gierz, I. Goffmann, and R. Sennett himself, who consider the public sphere in terms of the behavior and interaction of people in it [18]. The latter approach is based on interactionism and seems to be the most informative in terms of considering new types of partnerships. Acting out social roles before the public according to I. Hoffmann (which A. Hochschild also refers to in his works), R. Sennett sees it as a symptom of a modern disease, a disease of a public person. The main receptacles of the public sphere are cities with a huge number of public places - theaters, squares, parks and other things [19].

Under the influence of developing capitalism (late, modern, postmodern, in various definitions), which destroys public space, people who were striving for publicity and its ordering began trying to avoid it, choosing a family as a refuge, considering it a space inviolable - on the one hand. On the other hand, the family became an indicator of a kind of morality in public: the family is an ideal model of relationships, public extra-family relationships are immoral. That is, public space on the one hand dictates patterns of perception of family relationships, on the other hand, the family delimits from this public space. Actively developing secularization processes in cities led to the desire to remain in the private sphere as a more moral sphere. But at the same time, the boundaries of the public and the private began to blur, family and friends often became actors in the public sphere, and privacy was dissolved in the public, private feelings began to be shown publicly. This led to the emergence of so-called "dead spaces" [19]. The point is that if previously the public space was a space for communication, now it is a space for movement, people are not so much located, staying in public space as moving around it. "Dead public space becomes the reason that people begin to search in the personal for what they were denied on someone else's territory" [16, p. 160]. Such searches require, on the one hand, time, and on the other hand, the constancy and stability of family relations in their classical sense do not guarantee the completion of the lack of a vibrant public space, but the absence of such a guarantee provides a prerequisite for choosing an alternative to such relations.

All this ultimately leads to the folding of the private to one's "I" alone. Z. Bauman in this context spoke of the process of individualization as a process in which collective forms of action are insignificant to achieve social goals, in the same process an individual has to cope with the so-called life challenges [20]. If before private space is the space of the family, then as the boundaries between the family and the public dissolve, the family leaves the private space. And since earlier for an individual a private space consisted of a family, it turns out that now his private space is one him. He can hide from public life, be left alone with himself, which leads to the emergence of distant relations. 
Heuristic potential of emotional labor concepts...

When a city erases established boundaries and labor relations enter personal space, the problem of balancing personal and public, the choice of a particular strategy of behavior, the logic of communication with the environment so that the boundaries of personal and public were at least outlined for the individual. How to distance one or another social connection, whom to bring closer to personal space, and whom - not? The individual, in fact, has to make a choice between trust and distrust of anyone.

The problem of trust in sociology is that the term is used so often that its content is intuitively clear, but not completely defined. This is indicated by the Italian sociologist D. Gambetta: “...the prevalence (of this term - D. Y.) apparently produced less analysis than paralysis: in the social sciences, the importance of trust is often recognized, but rarely studied, and scientists, as a rule, mention it only briefly, referring to it as the main component or lubricant, an inevitable measurement of social interaction, only to move on to solving less complex issues. This is clearly the case when the growing specialization of the social sciences prevents a thorough investigation" [21, p. 12]. This quote reflects the author's position that trust should be one of the central categories in the study of social. In our opinion, the category of trust can have a heuristic potential for explaining the spread of single living only when its content is clearly defined.

Considering the problems of Italy since its inception as a politically united nation, he does not see any effective explanations among those proposed at that time - neither structural nor cultural. In an attempt to explain, he comes to the conclusion that it is necessary to investigate "...the causality of cooperation from the point of view of the faith on which cooperation is based, namely trust. The importance of trust pervades a variety of situations where cooperation is both a vital and fragile product: from marriage to economic development, from buying a used car to international relations..." [21, p. 10]. The importance of trust does not fade away in any interpersonal relationship, however, trust always involves risks, the need for risks is also considered by the author from an economic point of view, but despite the economic orientation of a social scientist, he nevertheless considers not only this side of social life, applying his model. So, he approaches the area of interest to us in a study conducted jointly with J. Ermish, whose goal was to test one hypothesis of the Japanese scientist Toshio Yamagishi, according to which strong and stable relationships (in particular, family relationships) "contribute to feelings of security in such relationships, but jeopardize trust that goes beyond that relationship" [22, pp. 365-376]. That is, people with strong family ties are less likely to trust strangers and take risks than people without strong ties. This is due to the motivation and the need to make new acquaintances: it is assumed that people with close family ties receive all the necessary communications for themselves in the family and close friends and do not need additional connections, and people without close ties compensate for this drawback with new acquaintances, respectively, trust and risk. According to this logic, we can assume that "solo-living" will tend to trust people as a representative of the same nuclear families, as they are really forced to compensate for the lack of communication in the "outside world". For example, in his work "Going Solo", E. Kleinenberg points out the fact that those who prefer life alone are really more active in social life: they have more social connections, are more prone to volunteering, etc. [17]. After conducting their experiment, D. Gambetta and J. Ermisch concluded that the strength 
Yashkina D.D.

of an individual's family ties does inversely correlate with trust in strangers. The results partially confirm the hypothesis that people with weaker ties with their family often trust strangers. The result of this study also demonstrates a number of contradictions with the theoretical developments of T. Yagimashi, however, in this case, we are interested in the indicated result [22]. Based on this, we can conclude that, in a situation where family ties are not strong (that is, when the family leaves the private space), the individual is forced to interact with a large number of people to meet their needs. Moreover, each such cooperation spends a resource of trust, but the likelihood of its success is much lower than in family conditions, so the number of such ties is increasing. And the propensity for greater trust in strangers becomes a necessity. People with weak family ties are potential "solo-living" ones $^{4}$, and this study may explain what E. Kleinenberg spoke about, but a number of questions arise. For example, whether quantitatively large social connections can compensate for qualitatively large social connections. Another question is how "solo-living" can satisfy the need for care as a function and as a practice, for example, having many social connections, but relatively (family) weak ones. How forced are such weak social ties, that is, are "solo-living" hostages of their own kind? How equivalent is a strong family connection and communication and a large number of weak ties, how comfortable "solo-living" can feel in this regard? When studying "solo-living" these questions become research important and the answers to them will clarify the very essence of the phenomenon.

Thus, we see how modern capitalism narrows the personal space, transforming it into public space (in the understanding of public space by R. Sennett). When the senses are a part of the work, then, returning from work, the individual does not find the strength to continue to work on the market, but rather for themselves.

Of course, we are speaking about critical manifestations of folding personal space, the commercialization of feelings, forced trust, but this can partially explain the processes of individualization, which sociologists so often speak about. There are still a lot of concepts, which may also have an explanation of the transformation of the family and its role, but the three presented here reflect several dimensions: spatial, emotional and rational. In the end, we see that it is easier for a modern working person to be alone when he / she needs personal space than to share this space with someone else.

In the current situation, the role of games also flushes the development of technology, people can stay connected while being physically in different spaces, cities, countries, etc. Being in the "dead public space", according to R. Sennett, they can be in the virtual space. Internet connections allow you to independently adjust the distance between individuals trying to maintain personal space. On the other hand, our gadgets are becoming an integral part of us, we carry our personal space in our pockets. With the development of technology and the market, the number of professions that are associated with emotional work is also increasing, there are more and more "stewardess" professions (when emotional inclusion becomes a required part of professional skills). Thus, emotional work is present in

\footnotetext{
${ }^{4}$ Only potentially, because in this case we need to understand what we mean by "weak family ties": can a strong bond with parents be considered a strong family bond even if, for example, the condition of separate living, etc.
} 
Heuristic potential of emotional labor concepts...

all spheres of life, from cashiers to admissions officers at universities, and the trend of the emergence of new forms of partnership continues to develop as a way to reduce the costs of such labor.

Conclusion. E. Kleinenberg, already mentioned by us, calls our time "the time of loners" [17]. We see that all the alternative forms of the family are somehow connected with the fact that the individual spends more time alone, in particular, for example, lives alone, separately. However, the question arises: are these new forms compelled or voluntary, what is their specificity and how to operationalize the new forms - answers to these questions will determine how to study "solo-living" in the future and determine its place in the structure of social changes.

The study is not comprehensive, it is necessary to clearly distinguish between various forms of partnerships before going into a qualitative conceptual analysis, since, as already noted, the spatial distinction, for example, for distance relationships and for "solo-living" can be completely different. In addition, it also depends on what we include in the "solo-living" category.

The concepts we studied have heuristic potential for the analysis of these phenomena, but they are neither comprehensive nor exhaustive: the concept of A.R.Hochschild concerns mainly women, although in the context of the given problems it is necessary to take into account not only the female part of society; the "fall of a public person" focuses on urban space (R. Sennett), but globalization processes erase the boundaries between cities and borders between countries, making the space global, which also needs to be taken into account, especially when it comes to relations at a distance; the problem of trust is considered in a rather narrow vein (D. Gambetta): namely, in the key of interpersonal trust and the strength of social ties, but this is not about trust in institutions, for example.

At the same time, the conducted research opens the following questions: what role does emotional work play in choosing "solo-living", and are "solo-living" really engaged in the field of emotional work? What is the public space for different forms of partnerships? How does the "distinction" between personal and public spaces for relationships at a distance work, and what role does Internet technology play in this? How equivalent is a strong family connection and communication and a large number of weak ties, how comfortable "sololiving" can feel in this regard? Is it possible to generally synthesize these concepts as an explanatory model for the development of various forms of partnerships? These questions represent the prospects for further research in a given way.

\section{References}

1. The Future of Families to 2030. A synthesis report. URL: https://www.oecd.org/ futures/49093502.pdf

2. Jurkane-Hobein, I. (2015). I Imagine You Here Now. Relationship Maintenance Strategies in Long-Distance Intimate Relationships. Digital Comprehensive Summaries of Uppsala Dissertations from the Faculty of Social Sciences 108. Uppsala: Acta Universitatis Upsaliensis.

3. Baranwal, J. Ram, B. (1985). Societal Development, Familialism and Solo Living: A CrossNational Study. Journal of Comparative Family Studies, 16 (1), 61-73. https://doi.org/10.3138/jcfs.16.1.61

4. Goode, W. (1970). World revolution and family patterns. New York: Collier-Macmillan. 
Yashkina D.D.

5. Keilman, N. (1988). Recent trends in family and household composition in Europe. European Journal of Population, 3 (3/4), 297-325. https://doi.org/10.1007/BF01796903

6. Ayad, M., Barrer, B., Otto, J. (1997). Demographic and socioeconomic characteristics of households. Demographic and Health Surveys Comparative Studies, 26. Calverton: Macro International Inc. URL: https://dhsprogram.com/pubs/pdf/CS26/CS26.pdf

7. Bongaarts, J. (2001). Household size and composition in the developing world in the 1990s. Population Studies, 55 (3), 263-279. https://doi.org/10.1080/00324720127697

8. Fokkema, T., Liefbroer, A. (2008). Trends in living arrangements in Europe: Convergence or divergence? Demographic Research, 19, 1351-1418. https://doi.org/10.4054/demres.2008.19.36

9. Stone, J., Berrington, A., Falkingham, J. (2011). The changing determinants of UK young adults' living arrangements. Demographic Research, 25, 629-666. https://doi.org/10.4054/DemRes.2011.25.20

10. Simonova, O. (2019). Emotional Culture as Sociological Concept: On Emotional Turn in Knowledge and society. URL: https://www.hse.ru/data/2019/05/22/1508325674/\%D0\%90\%D0\% BF\%D1\%80\%D0\%B5\%D0\%BB\%D1\%8C\%D1\%81\%D0\%BA\%D0\%B0\%D1\%8F_\%D0\%BA\%D0\%BE $\% \mathrm{D} 0 \% \mathrm{BD} \% \mathrm{D} 1 \% 84 \_\% \mathrm{D} 0 \% \mathrm{~A} 1 \% \mathrm{D} 0 \% \mathrm{BE} \% \mathrm{D} 1 \% 86 \% \mathrm{D} 0 \% \mathrm{~B} 8 \% \mathrm{D} 0 \% \mathrm{BE} \% \mathrm{D} 0 \% \mathrm{BB} \% \mathrm{D} 0 \% \mathrm{BE} \% \mathrm{D} 0 \% \mathrm{~B} 3 \% \mathrm{D}$ 0\%B8\%D1\%8F_\%D0\%A1\%D0\%B8\%D0\%BC\%D0\%BE\%D0\%BD\%D0\%BE\%D0\%B2\%D0\%B0_\%C2 $\% \mathrm{AB} \% \mathrm{D} 0 \% \mathrm{AD} \% \mathrm{D} 0 \% \mathrm{BC} \% \mathrm{D} 0 \% \mathrm{BE} . . \% \mathrm{D} 0 \% \mathrm{~B} 8 \% \mathrm{D} 1 \% 87 \% \mathrm{D} 0 \% \mathrm{~B} 5 \% \mathrm{D} 1 \% 81 \% \mathrm{D} 0 \% \mathrm{BA} \% \mathrm{D} 0 \% \mathrm{~B} 0 \% \mathrm{D} 1 \% 8$ F\%20\%D0\%BA\%D0\%BE\%D0\%BD\%D1\%86\%D0\%B5\%D0\%BF\%D1\%86\%D0\%B8\%D1\%8F_\%D0\%9 F\%D0\%BE\%D0\%BB\%D0\%BD\%D0\%B0\%D1\%8F_\%D0\%B2\%D0\%B5\%D1\%80\%D1\%81\%D0\%B8\%D $1 \% 8$ F.pdf

11. Hochschild, A.R. (2003). The managed heart: commercialization of human feeling. Berkeley, CA: University of CA Press. URL: https://caringlabor.files.wordpress.com/2012/09/the-managed-heart-arlierussell-hochschild.pdf

12. Simonova, O. (2013). Emotional labor in modern society: rethinkihg and conceptualizing ideas of A.R. Hochschild. The Journal of Social Policy Studies, 11 (3), 339-354. URL: https://cyberleninka.ru/article/n/emotsionalnyy-trud-v-sovremennom-obschestve-nauchnye-diskussii-idalneyshaya-kontseptualizatsiya-idey-a-r-hohshild/viewer [in Russian]

13. Hochschild, A., Machung, A. (2003b). The second shift. New York: Penguin Books.

14. Sociologist Elena Zdravomyslova - about the "unproductive" oldness and pain of the "sandwich generation". (2016). The Village. URL: https://www.the-village.ru/village/people/city-news/232683sandwich-generation [in Russian]

15. Goffman, I. (2000). The Presentation Self in Every Day Life. Moscow: Kanon-press-Ts. URL: https://cfs.hse.ru/data/2016/04/07/1127142131/\%D0\%93\%D0\%BE\%D1\%84\%D0\%BC\%D0\%B0\%D0\%B D\%20-\%20\%D0\%9F\%D1\%80\%D0\%B5\%D0\%B4\%D1\%81\%D1\%82\%D0\%B0\%D0\%B2\%D0\%BB\% D0\%B5\%D0\%BD\%D0\%B8\%D0\%B5\%20\%D1\%81\%D0\%B5\%D0\%B1\%D1\%8F\%20\%D0\%B4\%D1\%80 $\% \mathrm{D} 1 \% 83 \% \mathrm{D} 0 \% \mathrm{~B} 3 \% \mathrm{D} 0 \% \mathrm{~B} 8 \% \mathrm{D} 0 \% \mathrm{BC} \% 20 \% \mathrm{D} 0 \% \mathrm{~B} 2 \% 20 \% \mathrm{D} 0 \% \mathrm{BF} \% \mathrm{D} 0 \% \mathrm{BE} \% \mathrm{D} 0 \% \mathrm{~B} 2 \% \mathrm{D} 1 \% 81 \% \mathrm{D} 0 \%$ $\mathrm{B} 5 \% \mathrm{D} 0 \% \mathrm{~B} 4 \% \mathrm{D} 0 \% \mathrm{BD} \% \mathrm{D} 0 \% \mathrm{~B} 5 \% \mathrm{D} 0 \% \mathrm{~B} 2 \% \mathrm{D} 0 \% \mathrm{BD} \% \mathrm{D} 0 \% \mathrm{BE} \% \mathrm{D} 0 \% \mathrm{~B} 9 \% 20 \% \mathrm{D} 0 \% \mathrm{~B} 6 \% \mathrm{D} 0 \% \mathrm{~B} 8 \% \mathrm{D} 0 \%$ B7\%D0\%BD\%D0\%B8\%20(2000).pdf [in Russian]

16. Vershinina, I. (2012). Sociology of the city by Richard Sennett: Transformation of the Public Sphere. Vestnik Moskovskogo Universiteta. Sotsiologiya i politologiya - Journal of Moscow University. Sociology and Political Science, 18, 4, 154-161. URL: https://www.socio.msu.ru/vestnik/archive/ text/2012/4/10.pdf [in Russian]

17. Kleinenberg, E. (2018). Going solo: The Extraordinary Rise and Surprising Appeal of Living Alone. Moscow: ANF [in Russian]

18. Sennet, R. (2002). The Fall of a Public Man. URL: https://bookap.info/book/ sennet_padenie_publichnogo_cheloveka/

19. Lebedeva, N. (2012). Book Review: Sennet R. The Fall of a Public Man. Sotsiologiya vlasti - Sociology of Power, 6-7 (1), 282-287. URL: https://www.academia.edu/13082618/ \%D0\%A0\%D0\%B5\%D1\%86\%D0\%B5\%D0\%BD\%D0\%B7\%D0\%B8\%D1\%8F_\%D0\%BD\%D0\%B0_\% 
Heuristic potential of emotional labor concepts...

D0\%BA\%D0\%BD\%D0\%B8\%D0\%B3\%D1\%83_\%D0\%A1\%D0\%B5\%D0\%BD\%D0\%BD\%D0\%B5\%D1 $\% 82 \_\% \mathrm{D} 0 \% \mathrm{~A} 0 . \% \mathrm{D} 0 \% 9 \mathrm{~F} \% \mathrm{D} 0 \% \mathrm{~B} 0 \% \mathrm{D} 0 \% \mathrm{~B} 4 \% \mathrm{D} 0 \% \mathrm{~B} 5 \% \mathrm{D} 0 \% \mathrm{BD} \% \mathrm{D} 0 \% \mathrm{~B} 8 \% \mathrm{D} 0 \% \mathrm{~B} 5 \% \% \mathrm{D} 0 \% \mathrm{BF} \% \mathrm{D} 1 \%$ $83 \% \mathrm{D} 0 \% \mathrm{~B} 1 \% \mathrm{D} 0 \% \mathrm{BB} \% \mathrm{D} 0 \% \mathrm{~B} 8 \% \mathrm{D} 1 \% 87 \% \mathrm{D} 0 \% \mathrm{BD} \% \mathrm{D} 0 \% \mathrm{BE} \% \mathrm{D} 0 \% \mathrm{~B} 3 \% \mathrm{D} 0 \% \mathrm{BE} \% \mathrm{D} 1 \% 87 \% \mathrm{D} 0 \% \mathrm{~B} 5 \%$ D0\%BB\%D0\%BE\%D0\%B2\%D0\%B5\%D0\%BA\%D0\%B0 [in Russian]

20. Bauman, Z. (2005). Individualized society. Moscow: Logos [in Russian]

21. Gambetta, D. (Ed.). (2008). Trust: making and breaking cooperative relations. Oxford: University of Oxford. URL: http://www.nuffield.ox.ac.uk/users/gambetta/Trust_making\%20and\%20breaking\% 20cooperative\%20relations.pdf

22. Ermisch, J., Gambetta, D., (2010). Do strong family ties inhibit trust? Journal of Economic Behavior \& Organization, 75 (3), 365-376. https://doi.org/10.1016/j.jebo.2010.05.007

Received on 14.03.20 